\title{
Contextual teaching-learning method to improve student engagement among college students in cognitive psychology course
}

\author{
Hazhira Qudsyi ${ }^{1}$, Hariz Enggar Wijaya ${ }^{2}$, Nur Widiasmara ${ }^{3}$, Fani Eka Nurtjahjo ${ }^{4}$ \\ ${ }^{1}$ Universitas Islam Indonesia, Yogyakarta - Indonesia, (hazhira.qudsyi@uii.ac.id)
}

\begin{abstract}
This study focus on how contextual teaching-learning (CTL), as one of learning method, can improve student engagement. Participants of this study were 156 college students in Yogyakarta, Indonesia. The study was conducted with an experimental approach. Measurement of student engagement was done by using School Engagement Scale. This scale was adapted into Indonesia version, and it has Cronbach's Alpha coefficient 0.859 with 15 items. Result of data analysis showed that there was a significant difference on student engagement among college students $(\mathrm{p}=0.042)$, but student engagement scores in posttest was smaller than scores in pretest ( N Negative Ranks $=83$, Mean rank $=78.20 ; \mathrm{N}$ Positive Rank $=64$, Mean rank $=68.55$; Ties $=9$ ). Additional analysis was also discussed in this study.From this result, we can conclude that CTL not effective to improve student engagement among college students. Results and limitations of this study are discussed further in this paper.
\end{abstract}

Keywords: student engagement, contextual teaching-learning (CTL), college students.

\section{Introduction}

One of mission from Department of Psychology Universitas Islam Indonesia is to conduct professional, innovative, information technology-based psychology education and based on prophetic values demands an innovative learning process and in accordance with the context of everyday life. One of these efforts is done through Cognitive Psychology course, conducted for students in second semester. Cognitive Psychology is a compulsory course that must be taken by students. This course is a series of learning process related to theoretical and applied competence in students. On theoretical competence, students are expected to understand theoretical approaches, findings, and major history in psychology. In applied competence, students are expected to understand the application of psychology to personal, social, organizational and Islamic issues.

Cognitive psychology deals with how individuals gain information from the world, how information is represented and transformed as knowledge, how it is stored and how knowledge is used to direct our attention and behavior. Cognitive Psychology is a course that honed the sensitivity to the surrounding environment by observing behavior of individuals and groups as a picture of thinking process that occurs in brain. Observed phenomena can be derived from individual's own experiences, other individuals, and groups that are often encountered in everyday life. 
Outcomes of Cognitive Psychology course are students able to explain definitions, theories, and research related concepts studied in Cognitive Psychology. Students are able to understand the results of research related to the basics of cognitive processes (memory, attention, perception, etc.). Students are able to identify and explain the concepts of Cognitive Psychology in everyday life. Ideally, when students have completed Cognitive Psychology course, students are able to achieve the outcomes previously mentioned.

Based on our experiences along teaching of Cognitive Psychology, we can see that there was a tendency for students to have difficulty in understanding concepts of Cognitive Psychology. This can be seen from students' respond that tend to be less active during learning process, lack of understanding from students when lecturers review course material, lack of feedback from students when lecturer explains course material, as well as from conversations between lecturers and students outside lectures related to learning process of Cognitive Psychology which is deemed to be ineffective because of too much material load for 2 credits lectures. Students also complain about learning that too much theoretical level, and minimal practice or applied activities.

Looking at phenomenon that occurs, it can be seen that students are still less actively involved in learning process. Active involvement of students in learning process becomes something important, because this can be one indicator of student understanding of material presented by lecturer. Just like Kuh said, that involvement of students could be used as an indicator of institutional teaching quality (Beer, Clark, \& Jones, 2010). In many literatures, involvement of students like this often referred to as student engagement. Engagement itself defined by Stovall as a combination of students' time on task and their willingness to participate in activities (Beer et al., 2010). Fredricks et al (Adelman \& Taylor, 2011; Fredricks \& Mccolskey, 2012)specifically define student engagement as a meta-construct that includes behavioral, emotional, and cognitive engagement. In line with Appleton, Christenson, and Furlong(2008), that engagement is typically described as having two or three components, like behavioral, emotional, and some researchers added with cognitive component. Another definition mentioned that, student engagement is refer to students' attitudes towards schooling and their participation in school activities (Willms, 2003). In university context, student engagement used to describe a compendium of behaviors characterizing students who are said to be more involved with their university community than their less engaged peers (Krause, 2005).

Why student engagement important in learning? Many researches shown that student engagement has many effect to positive behavior or positive result of student's learning. Just like Parsons and Taylor (2011)said, that student engagement is primarily and historically about increasing achievement, positive behaviors, and a sense of belonging in all students. Fredricks, Blumenfeld, and Paris (Adelman \& Taylor, 2011) conclude that student engagement is associated with positive academic outcomes, including achievement and persistence in school. Research by Korobova (2012)shown that student engagement can predict student satisfaction and academic success, that academic success measured by grades. Study also found that full engagement of students is strongly related to positive teacher-student relationships (Conner \& Pope, 2013). Research by Carini, Kuh, and Klein ( 2004)also found that student engagement was linked positively to desirable learning outcomes, such as critical thinking and grades level. Study also found that student engagement in educationally purposeful activities was positively related to academic outcomes and persistence among college students (Kuh, Cruce, Shoup, Kinzie, \& Gonyea, 2008). Student engagement also have indirectly positively related to learning activities (Bakker, Isabel, \& Vergel, 2015). And research by Li, Lerner, and Lerner(2010) concluded that student engagement was indirectly linked to academic competence. Considering the importance of student engagement into student's outcome and behavior, we need to put it in one of important aspect in students learning that we concerned about.

Many researches shown that student engagement behavior among students has many factors. Generally, factors that influence student engagement can be grouped by two main factors: internal factors and external factors. Internal factors of student engagement were perceived control (Guenther 
\& Miller, 2011), intrinsic motivation (Guenther \& Miller, 2011; Saeed \& Zyngier, 2012; Siu, Bakker, \& Jiang, 2014), self efficacy (Warwick, 2008), students emotion (Ryzin, 2011), academic autonomy (Guenther \& Miller, 2011; Ryzin, Gravely, \& Roseth, 2009), and students traits(Bakker et al., 2015). On the other hand, external factors of student engagement were emotional support (Park, Holloway, \& Arendtsz, 2012), peer support (Cappella, Yeon, Jennifer, \& Jackson, 2013; Doyle \& Richard, 2013; Ryzin, 2011), parental or family factors (Adelman \& Taylor, 2011; Smalls, 2009; Veiga et al., 2012), teachers support (Adena \& James, 2004; Chiu, Pong, \& Mori, 2012; Conner \& Pope, 2013), classroom context (Adelman \& Taylor, 2011; Dotterer \& Lowe, 2011; Li et al., 2010), and instructional strategies (Adelman \& Taylor, 2011; Delialioǧlu, 2012; Junco, Heiberger, \& Loken, 2011; Parsons \& Taylor, 2011; Welch \& Bonnan-White, 2012). Hence, many factors influence student engagement, we can see that instructional strategies, or sometimes we call it with learning strategies or learning method, being one of factors that proven has positive impact to student engagement.

Many learning strategies that can has impact to student engagement, and one of them is active learning. Just like Kuh et al said, that active learning techniques was effective for promoting student engagement (Guenther \& Miller, 2011). Examples of active learning practices that can enhance student engagement are incorporating summary assignments in which students are required to synthesize and integrate important concepts from assigned readings, asking students to generate references on a particular topic in paper, ensuring that discussions and debates are a normal classroom occurrence, and creating assignments that challenge students to seek answers beyond those presented in their basic textbook (Guenther \& Miller, 2011). One kind of learning strategies which is included in active learning is contextual teaching and learning (CTL). In line with Hudson and Whisler (2013), that a theoretical basis for CTL is focused on connection, constructivist, and active learning theories.

Sears (2003)stated that CTL is a concept that helps teachers relate subject matter to real-world situations. CTL is also defined as a way to introduce content using a variety of active learning techniques to help students to connect what they already know to what they are expected to learn, and to construct new knowledge from the analysis and synthesis of the learning process (Hudson \& Whisler, 2013). CTL is also known as contextual learning or contextual teaching. Miller (2006)said that contextual learning conditions require students to learn in dynamic environments that stimulate the reality of the work place, and it facilitates understanding, retention, recall, as well as two types of learning transfer, applications and use in new situations. In contextual learning, students must learn to apply their knowledge to effective thinkers, and acquire knowledge to the performance of tasks (Bond, 2004). With CTL, students can connect the content they are learning to the life contexts in which that content could be used, and students will draw upon their previous experiences and build upon existing knowledge(Berns \& Erickson, 2001).

Many studies have shown that CTL can be applied to improve students learning. CTL can improve higher order learning and transfer (P. M. Miller, 2006), effective to help engineering statistics students in their learning process (Kamaruddin, Rashid, Amin, \& Alias, 2012), improve students' reading skill in procedural texts (Khaefiatunnisa, 2015), improve students' problem solving skills (Suryawati, Osman, \& Meerah, 2010),encourage students to construct knowledge into their own mind (Sihono, 2004), and helping students to understanding learning material (Leksono, 2010). From the explanation before, we can see that CTL not only can improve students' achievement, but also can improve students' behavior. CTL also identified as a promising strategy that actively engages students and promotes improved learning and skills development (Baker, Hope, \& Karandjeff, 2009). As noted by Baker et al (2009), student engagement in contextual learning has deep roots.

Based on explanation above, we assumed that contextual teaching and learning (CTL) can improve student engagement among students. In this case, we choose to apply CTL among college students, considering reality occurred in Cognitive Psychology Course. So, this study aims to investigate effectiveness CTL to improve student engagement among college students in Cognitive Psychology 
Course. And hypothesis of this study, there is differences of student engagement between pretest and posttest, which is student engagement scores in posttest larger than student engagement scores in pretest.

\section{Method}

\section{Participants}

Participants of this study were 156 college students atUniversitas Islam Indonesia, whose attended Cognitive Psychology Class in 2016-2017.

\section{Research Design}

This study was conducted with quasi-experimental design to test effectiveness of Contextual Teaching-Learning (CTL) to improve student engagement among college students. Quasiexperimental design is kind of experimental design which has treatment, measurement of effect, experimental unit, but did not use random assignment to compare group, in order to conclude the changes caused by treatment (Shadish, Cook, \& Campbell, 2002). The type of quasi-experimental used in this study was the one group pretest-posttest design. Basically, this design is a quasi-experimental design that adds pretest to outcome construct (Shadish et al., 2002).

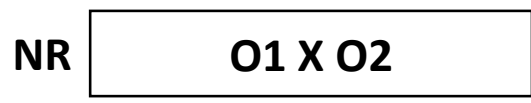

Picture 1. The one group pretest-posttest design (Shadish et al, 2002)

This study aims to test empirically effectiveness treatment (in this case, with contextual teaching and learning) to experiment group (without control group), which in this study will compare student engagement variable between pretest and posttest among participants. CTL used in this study based on Johnson's theory. As noted by Johnson (2014), CTL method includes eight components. These components are making meaningful attachments, doing meaningful work, doing self-directed learning working together, thinking critically and creatively, helping individuals to grow and develop, reaching high standards, and using authentic judgments (Johnson, 2014). These components applied in Cognitive Psychology Course with description below.

Table 1. Eight Components of CTL in Cognitive Psychology Course

\begin{tabular}{|c|c|}
\hline CTL components & Application in Cognitive Psychology Course \\
\hline Making meaningful attachments & $\begin{array}{l}\text { Applied in the form of demonstrations in lecture meetings, video / } \\
\text { documentation presentation, assignment, self-reflection }\end{array}$ \\
\hline Doing meaningful work & Applied in the assignment (individuals and groups), making self-reflection \\
\hline Doing self-directed learning & $\begin{array}{l}\text { Applied in various forms of assignment given to students, either individually } \\
\text { or groups }\end{array}$ \\
\hline Working together & Applied in the form of group assignments \\
\hline Thinking critically and creatively & $\begin{array}{l}\text { Applied in the form of discussion questions in the classroom, classroom } \\
\text { review, group discussion, self-reflection, various forms of assignment } \\
\text { (individuals and groups) }\end{array}$ \\
\hline $\begin{array}{l}\text { Helping individuals to grow and } \\
\text { develop }\end{array}$ & $\begin{array}{l}\text { Applied in classroom review sessions, various forms of assignment } \\
\text { (individuals and groups), various discussions in classroom and outside } \\
\text { classroom, making self-reflection }\end{array}$ \\
\hline Reaching high standards & Apply in formative formative evaluation (exams, quizzes), various forms of \\
\hline
\end{tabular}


individual assignments

Using authentic judgments Applied in various forms of assignment (individuals and groups)

\section{Technique of Data Collecting}

To collect data, this study used self-report scale to measure student engagement variable. Measurement of student engagement was done by using School engagement Scale which developed by Fredericks, Blumenfeld, and Paris (Sa'diyah \& Qudsyi, 2016). This scale was adapted into Indonesia version, and it has Cronbach's Alpha coefficient was 0.859 with 15 items. This scale has three subscales, namely behavioral engagement with 4 items, emotional engagement with 6 items, and cognitive engagement with 5 items(Sa'diyah \& Qudsyi, 2016).

\section{Data analysis}

Data analysis used in this studywas statistical analysis with Wilcoxon Sign Rank Test to test scores differences between pretest and posttest measurement. Variable measured in this study was student engagement.

\section{Results and Discussion}

Descriptive statistics of data can be seen on Table 2 below.

Table 2. Descriptive statistics

\begin{tabular}{cccccc}
\hline Variable & $\mathrm{N}$ & Minimum & Maximum & Mean & Standard Deviation \\
SE pretest & 156 & 35 & 75 & 51.45 & 5.406 \\
SE posttest & 156 & 41 & 63 & 50.46 & 4.420 \\
\hline
\end{tabular}

*SE $=$ student engagement

Description of participants can be seen on Table 3 below.

Table 3. Description of participants

\begin{tabular}{llcc}
\hline \multirow{3}{*}{ Gender } & Variable & Number & Percentages \\
& Male & 32 & 20.5 \\
Class of Cognitive Psychology Course & Female & 124 & 79.5 \\
& A & 42 & 26.9 \\
& B & 40 & 25.6 \\
& C & 43 & 27.6 \\
& D & 31 & 19.9 \\
& & 156 & 100 \\
\hline
\end{tabular}

Before we conducted hypothetical analysis, we analyzed the normality of data. And result shown in table 4.

Table 4. Normality test $(\mathrm{p}>0.05)$

\begin{tabular}{lccc}
\hline \multicolumn{1}{c}{ Variable } & $\mathbf{d f}$ & $\mathbf{p}$ & Meaning \\
SE pretest & 156 & 0.200 & Normal \\
SE posttest & 156 & 0.030 & Not normal \\
\hline \multicolumn{2}{c}{${ }^{*} \mathrm{SE}=$ student engagement } & &
\end{tabular}


Because of data was not normal, so we used Wilcoxon Sign Rank Test (Non parametric test) to test our hypothesis. Result of hypothesis test shown in Table 5.

Table 5. Hypothesis test (Wilcoxon Sign Rank Test)

\begin{tabular}{llccccc}
\hline \multicolumn{1}{c}{ Variable } & $\mathrm{N}$ & Mean Rank & $\begin{array}{c}\text { Sum of } \\
\text { Ranks }\end{array}$ & $\mathrm{Z}$ & $\mathrm{p}$ \\
$\begin{array}{l}\text { SE posttest }- \\
\text { SE pretest }\end{array}$ & $\begin{array}{l}\text { Negative } \\
\text { ranks } \\
\text { Positive } \\
\text { ranks } \\
\text { Total }\end{array}$ & 63 & 78.20 & 6490.50 & -2.038 & 0.042 \\
& 64 & 68.55 & 4387.50 & & \\
$(156$ & & & & \\
\hline
\end{tabular}

*SE $=$ student engagement

Based on data analysis above, we can see that there was a significant difference on student engagement among college students $(p=0.042)$, but student engagement scores in posttest was smaller than scores in pretest $(\mathrm{N}$ Negative Ranks $=83$, Mean rank $=78.20 ; \mathrm{N}$ Positive Rank $=64$, Mean rank $=$ 68.55; Ties $=9$ ).

Data analysis showed that hypothesisof this research, which contextual teaching and learning (CTL) can improve student engagement among college students in Cognitive Psychology Course, was not accepted. Empirical data showed that student engagement scores in posttest was smaller than student engagement scores in pretest. So we can conclude that in this study, CTL was not effective to improve student engagement among college students. There were several possiblereasons why the research hypothesis wasrejected.

Placement of participants into research groups was not done randomly (random assignment). Although participants of this study were not taken randomly (random sampling), placement of participants into experimental group should be done randomly. This random assignment is any form of procedure for placing units in an opportunity-based condition where each unit has a nonzero possibility to be placed under any circumstances (Shadish et al., 2002). Purpose of this random assignment according to Shadish et al (2002) is to facilitate causal conclusions by making random samples of the same study between one another. In line with Azwar (2005), groups of participants in experimental study were randomly generated. This randomization will support the assumptions about equality of two groups' conditions (if the experimental design requires minimum two groups), before the experiment is performed. Randomization allows researchers to assume that group 1 and group 2 are equivalent in terms of a certain average (for example, learning achievement)(Azwar, 2005).

In this study, all groups of research become experiment groups, which is divided into four classes. And each class was taught by one lecturer. Every class got contextual teaching and learning method from the lecturer. Even the concept of CTL method was the same for all class, but because in every class had different lecturer, it was possible if there was different style of teaching in each lecturer. When lecturers have different style of teaching, it can be able affect the learning process. And of course it can influence the process of CTL and the impact to variable that measured. As stated by Berns and Erickson (2001), for the CTL approaches to be most effective in student learning, teachers must plan, implement, reflect upon, and revise lessons. Such plans are based on CTL principles and approach that require teachers to serve in the following roles: facilitator, organizer of the teaching or learning or assessment process role model, learning mentor, content specialist, and knowledge dispenser (Berns \& Erickson, 2001). Teacher's role is important in CTL method, and it should apply in CTL process. 
Based on this study, there was no prove yet that CTL method can improve student engagement. Even CTL method use an active learning approach, which is possible to make student engage in learning, but learning method can not influence directly into student behavior, including student engagement. Every learning method that apply to students, influence directly into student performance or student achievement, as noted by few studies(Altun, 2015; Azmin, 2015; Dunlosky, Rawson, Marsh, Nathan, \& Willingham, 2013; Ganyaupfu, 2013; Greenwald \& Hedges, 1996; Haas, 2002).

\section{Conclusions}

Based on previous analysis, it can be concluded that contextual teaching and learning (CTL) method was not effective to improve student engagement. There were few explanations why this hypothesis was rejected, such as researchers did not divide the groups into experiment group randomly, no control group, possibility of different teaching styles and teaching roles. So, recommendation for next researchers is that they need to considering these research limitations if they want to investigate the same variable.

\section{References}

Adelman, H., \& Taylor, L. (2011). School Engagement, disengagement, learning supports, and school climate. Learning, (310).

Adena, M., \& James, P. (2004). Relationships Matter : Linking Teacher Support to Student Engagement and Achievement.

Altun, S. (2015). The Effect of Cooperative Learning on Students' Achievement and Views on the Science and Technology Course. International Electronic Journal of Elementary Education, 7(3), 451468.

Appleton, J. J., Chirstenson, S. L., \& Furlong, M. J. (2008). Student engagement with school: Critical conceptual and methodological issues of the construct. Psychology in the Schools, 45(5), 369-386. https://doi.org/10.1002/pits

Azmin, N. H. (2015). Effect of the Jigsaw-Based Cooperative Learning Method on Student Performance in the General Certificate of Education Advanced-Level Psychology: An Exploratory Brunei Case Study. International Education Studies, 9(1), 91. https://doi.org/10.5539/ies.v9n1p91

Azwar, S. (2005). Metode Penelitian. Yogyakart: Penerbit Pustaka Pelajar.

Baker, E. ., Hope, L., \& Karandjeff, K. (2009). Contextualized Teaching and Learning: A Faculty Primer. California.

Bakker, A. B., Isabel, A., \& Vergel, S. (2015). Student engagement and performance: A weekly diary study on the role of openness. Motivation Emotion, 39, 49-62. https://doi.org/10.1007/s11031-0149422-5

Beer, C., Clark, K., \& Jones, D. (2010). Indicators of engagement. In Proceedings of ASCILITE Sydney (pp. 75-86). https://doi.org/http://hdl.cqu.edu.au/10018/55464

Berns, R., \& Erickson, P. (2001). Contextual teaching and learning: Preparing students for the new economy. The Highlight Zone: Research, (5), 1-8.

Bond, L. (2004). Using contextual instruction to make abstract learning concrete. Techniques: Connecting Education \& Careers, 79(1), 30-34.

Cappella, E., Yeon, H., Jennifer, K., \& Jackson, D. R. (2013). Classroom Peer Relationships and Behavioral Engagement in Elementary School : The Role of Social Network Equity, 367-379. https://doi.org/10.1007/s10464-013-9603-5

Carini, R. M., Kuh, G. D., \& Klein, S. P. (2004). Student engagement and student learning: Testing the linkages. Research in Higher Education, (April), 1-44. 
Chiu, M. M., Pong, S., \& Mori, I. (2012). Immigrant Students' Emotional and Cognitive Engagement at School: A Multilevel Analysis of Students in 41 countries. Journal Youth Adolescence, 41, 14091425. https://doi.org/10.1007/s10964-012-9763-x

Conner, J. O., \& Pope, D. C. (2013). Not Just Robo-Students: Why Full Engagement Matters and How Schools Can Promote It. Journal of Youth and Adolescence, 42, 1426-1442. https://doi.org/10.1007/s10964-013-9948-y

Delialioğlu, Ö. (2012). Student engagement in blended learning environments with lecture-based and problem-based instructional approaches. Educational Technology and Society, 15(3), 310-322. https://doi.org/10.2307/jeductechsoci.15.3.310

Dotterer, A. M., \& Lowe, K. (2011). Classroom Context, School Engagement, and Academic Achievement in Early Adolescence. Journal Youth Adolescence, 40, 1649-1660. https://doi.org/10.1007/s10964-011-9647-5

Doyle, A., \& Richard, L. (2013). Adolescent Academic Achievement and School Engagement : An Examination of the Role of School-Wide Peer Culture, 6-19. https://doi.org/10.1007/s10964-0129833-0

Dunlosky, J., Rawson, K. A., Marsh, E. J., Nathan, M. J., \& Willingham, D. T. (2013). Improving students' learning with effective learning techniques: Promising directions from cognitive and educational psychology. Psychological Science in the Public Interest, 14(1), 4-58. https://doi.org/10.1177/1529100612453266

Fredricks, J. A., \& Mccolskey, W. (2012). The measurement of student engagement: A comparative analysis of various methods and student self-report instruments. In S. . Christenson (Ed.), Handbook of Research on Student Engagement (pp. 763-782). Springer Science+Business Media. https://doi.org/10.1007/978-1-4614-2018-7

Ganyaupfu, E. M. (2013). Teaching Methods a nd Students ' Academic Performance. International Journal of Hummanities and Social Science Invention, 2(9), 29-35.

Greenwald, R., \& Hedges, L. V. (1996). The Effect of School Resources on Student Achievement. Review of Educational Research, 66(3), 361-396.

Guenther, C., \& Miller, R. . (2011). Factors that promote engagement. In R. L. Miller, E. Amsel, B. M. Kowalewski, B. C. Beins, K. D. Keith, \& B. F. Peden (Eds.), Promoting student engagement (Vol 1): Programs, techniques and opportunities (Vol. 1, pp. 10-17). Society for the Teaching of Psychology. Retrieved from http://teachpsych.org/ebooks/pse2011/index.php

Haas, M. S. (2002). The Influence of Teaching Methods on Student Achievement on Virginia's End of Course Standards of Learning Test for Algebra I. Virginia Polytechnic Institute and State University.

Hudson, C. C., \& Whisler, V. R. (2013). Contextual teaching and learning for practitioners. Systemics, Cybernetics and Informatics, 6(4), 54-58.

Johnson, E. . (2014). CTL: Contextual Teaching and Learning. Bandung: Penerbit Kaifa.

Junco, R., Heiberger, G., \& Loken, E. (2011). The effect of Twitter on college student engagement and grades. Journal of Computer Assisted Learning, 27(2), 119-132. https://doi.org/10.1111/j.13652729.2010.00387.x

Kamaruddin, N. K. ., Rashid, W. M., Amin, Z. ., \& Alias, M. (2012). A Study of the Effectiveness of The Contextual Approach to Teaching and Learning Statistics at the Universiti Tun Hussein Onn Malaysia (UTHM). International Journal of Arts \& Sciences, 4(25), 305-313.

Khaefiatunnisa. (2015). The effectiveness of contextual teaching and learning in improving students' reading skill in procedural text (A quasi-experimental study of the second grade students at one vocational school in Bandung). Journal of English and Education, 3(1), 80-95.

Korobova, N. (2012). A comparative study of student engagement, satisfaction, and academic success among international and American students. Graduate Theses and Dissertations. Iowa State University. https://doi.org/10.1353/csd.2006.0060

Krause, K. (2005). Understanding and promoting student engagement in university learning communities. In Sharing Scholarship in Learning and Teaching: Engaging Students (pp. 1-15). Queensland: James Cook University Symposium. Retrieved from 
http://cshe.unimelb.edu.au/resources_teach/teaching_in_practice/docs/Stud_eng.pdf

Kuh, G. D., Cruce, T. M., Shoup, R., Kinzie, J., \& Gonyea, R. M. (2008). Unmasking the Effects of Student Engagement on First-Year College Grades and Persistence. The Journal of Higher Education, 79(5), 540-563. https://doi.org/10.1353/jhe.0.0019

Leksono, A. B. (2010). Model pembelajaran Contextual Teaching and Learning (CTL) dalam proses belajar mengajar mata pelajaran sosiologi kelas X pada pokok bahasan nilai dan norma sosial di SMA Negeri 1 Tanjung Kabupaten Brebes Tahun Ajaran 2010/2011.

Li, Y., Lerner, J. V, \& Lerner, R. M. (2010). Personal and Ecological Assets and Academic Competence in Early Adolescence: The Mediating Role of School Engagement. Journal Youth Adolescence, 39, 801-815. https://doi.org/10.1007/s10964-010-9535-4

Miller, P. M. (2006). Contextual Learning May Be a Better Teaching Model: a Case for Higher Order Learning and Transfer. Allied Academies International Conference, 11(2), 19-24.

Park, S., Holloway, S. D., \& Arendtsz, A. (2012). What Makes Students Engaged in Learning ? A Time-Use Study of Within- and Between-Individual Predictors of Emotional Engagement in Low-Performing High Schools, 390-401. https://doi.org/10.1007/s10964-011-9738-3

Parsons, J., \& Taylor, L. (2011). Student engagement: What do we know and what should we do?the University Partners. Retrieved from https://education.alberta.ca/media/6459431/student_engagement_literature_review_2011.pdf

Ryzin, M. J. Van. (2011). Protective Factors at School: Reciprocal Effects Among Adolescents' Perceptions of the School Environment, Engagement in Learning, and Hope. Journal Youth Adolescence, 40, 1568-1580. https://doi.org/10.1007/s10964-011-9637-7

Ryzin, M. J. Van, Gravely, A. A., \& Roseth, C. J. (2009). Autonomy, Belongingness and Engagement in School as Contributors to Adolescent Psychological Well-Being. Journal Youth Adolescence, 38, 112. https://doi.org/10.1007/s10964-007-9257-4

Sa'diyah, S. K., \& Qudsyi, H. (2016). Peer support and student engagement among high-school students in Indonesia. In International Conference on Education, Psychology, and Social Sciences. University Kuala Lumpur and Knowledge Association of Taiwan. https://doi.org/ISSN 25182498

Saeed, S., \& Zyngier, D. (2012). How Motivation Influences Student Engagement: A Qualitative Case Study. Journal of Education and Learning, 1(2), 252-267. https://doi.org/10.5539/jel.v1n2p252

Sears, S. (2003). Introduction to Contextual Teaching and Learning. Bloomington: Phi Delta Kappa Educational Foundation.

Shadish, W. R., Cook, T. D., \& Campbell, D. . (2002). Experimental and Quasi-Experimental Designs for Generalized Causal Inference. Boston: Houghton Mifflin Company.

Sihono, T. (2004). Contextual Teaching and Learning Sebagai Model Pembelajaran Ekonomi dalam KBK. Jurnal Ekonomi Dan Pendidikan, 1(1), 63-83.

Siu, O. L., Bakker, A. B., \& Jiang, X. (2014). Psychological Capital Among University Students: Relationships with Study Engagement and Intrinsic Motivation. Journal of Happiness Study, 15, 979-994. https://doi.org/10.1007/s10902-013-9459-2

Smalls, C. (2009). African American Adolescent Engagement in the Classroom and Beyond : The Roles of Mother ' s Racial Socialization and Democratic-Involved Parenting, 204-213. https://doi.org/10.1007/s10964-008-9316-5

Suryawati, E., Osman, K., \& Meerah, T. S. M. (2010). The effectiveness of RANGKA contextual teaching and learning on student's problem solving skills and scientific attitude. Procedia - Social and Behavioral Sciences, 9, 1717-1721. https://doi.org/10.1016/j.sbspro.2010.12.389

Veiga, F. H., Galvão, D., Almeida, A., Carvalho, C., Janeiro, I., Nogueira, J., ... Pereira, T. (2012). Student's engagement in school: A literature review. In Proceedings of ICERI2012 Conference (pp. 1336-1344).

Warwick, J. (2008). Mathematical self-efficacy and student engagement in the mathematics classroom, $8(3)$.

Welch, B. K., \& Bonnan-White, J. (2012). Twittering to increase student engagement in the university 
classroom. Knowledge Management and E-Learning, 4(3), 325-345.

Willms, J. D. (2003). Student engagement at school: A sense of belonging and participation (Result from PISA 2000). OECD. https://doi.org/10.1787/19963777 